\title{
International Criminal Court and its Relationship with the Security Council
}

\author{
Abdallah Al-Khseilat \\ Faculty of Law \\ Middle East University (MEU) \\ Jordan \\ Salem Mekhled Salem AlHamlan \\ Mutah University - Jordan \\ Ayman Yousif Al - refou \\ Middle East University Jordan (MEU) \\ Jordan
}

\begin{abstract}
The International Criminal Court (ICC) was created to try people who commit the most serious crimes of international concern. The basic principle is that the International Criminal Court is far from political currents, as it is considered an independent body with legal personality, which exercises its functions in complete independence. However, its relationship with the Security Council is weaker than this independence and the powers it enjoys, as the Security Council has the authority to refer the case to the court, and it has the power to defer investigation or prosecution.
\end{abstract}

Keywords: International Criminal Court- veto power- refer the case to the court- deferral of investigation- maintain international peace and security.

\section{Introduction:}

The international community began moving towards establishing rules to protect the basic rights and freedoms of humans. The efforts exerted to establish international criminal courts increased, and these efforts were finally crowned by the adoption of the statute of the permanent international criminal court on July 17, 1998 AD. This court was established for the purpose of trying people who commit the most serious crimes of international concern.

After the wars and crises of the last century and the resulting disasters that affected humanity, the dream became a reality. The International Criminal Court was established to reflect the will of the international community to combat and fight the most serious crimes at the international level, including genocide, crimes against humanity, war crimes and aggression, which is considered one of the most important achievements for humanity.

The idea of establishing an international criminal court is an old idea that dates back to the League of Nations, but the call to expedite the establishment of a statute for this court was given priority since 1993.

At the end of 1994, the International Law Commission developed its draft statute for the International Criminal Court and submitted it to the General Assembly that discussed it, until it decided on December 17, 1996 that a diplomatic conference for plenipotentiaries should be convened in 1998 with the purpose of completing and adopting an agreement on the establishment of an international criminal court.

According to the invitation of the Italian government, Italy hosted that conference from 15 June to 17 July 1998, which ended on the evening of July 17 of the same year to approve what became known as the "Statute of the International Criminal Court", which 120 countries agreed to. 7 countries opposed it and 21 countries abstained from voting. 1 This statute is found in 13 chapters distributed over 116 articles, and it entered into force on 1/7/2002, after the completion of the ratification of this system by 60 countries.

\section{Research problem:}

This system, even if it constitutes an important historical event, was reached after serious and strenuous efforts. However, it is not without some negative aspects, the most important and most serious of which is the relationship of the International Criminal Court with the International Security Council.

${ }^{1}$ Dr.SawsanBakkah, Aljara'im Dida Al'iinsaniah Fi Daw' An-Nizam Al-'AsasiLilmahkamaAljina'iya Ad-Dawlia (Crimes Against Humanity in the Light of the Statute of the International Criminal Court), PhD Thesis, Faculty of Law, Cairo University, 2004, p. 85 and beyond. 
It is assumed that the International Criminal Court is far from political currents, as it is, as stated in its statute, an independent body with legal personality and eligibility which exercises its functions in complete independence, but what was stipulated regarding its relationship with the Security Council raises the question. The Security Council has the authority to refer the case to the court, and it has the power to defer investigation or prosecution.

\section{Research plan:}

First topic: The powers of the Security Council towards the court

Second topic Assessment of the relation of International Criminal Court and United Nations Security Council.

\section{First topic:}

\section{The powers of the Security Council towards the court}

In this topic, we will try to introduce the powers that the Security Council has with regard to the International Criminal Court, dividing this topic into two main sections, the first deals with the authority of the Security Council to refer the case to the court. The second deals with the authority of the council to defer investigation or prosecution before the International Criminal Court. 2

\section{Section I: The Council's power to refer the case to the court:}

The Rome Statute stipulated that "the Security Council has the right, acting under Chapter VII3 of the Charter of the United Nations, to refer to the Prosecutor of the International Criminal Court a situation in which one or more of the crimes, for which the Court is competent to consider under Article V of the Statute, appears to have been committed / A. 13 p. (b).

In order for the Security Council to refer a case to the International Criminal Court, a decision in this regard must be issued by the Council itself. In order for this decision to be issued, a vote must be held within the Council concerning it. Since voting in the Security Council is of a special nature that differs from other international and regional bodies and authorities. In the following lines, we will try to explain the voting procedures in it. Then we will see the extent to which the Security Council's decision is mandatory for the Prosecutor and the International Criminal Court to conduct investigation.

\section{1- Voting procedures of the Security Council: 4}

If voting in the Security Council is based on granting each member one vote without distinction between permanent and non-permanent members, in accordance with the Public International Law which states the necessity of equality among countries, it maintains at the same time the distinction between the Big Five Countries which are granted the Veto Power regarding any of the substantive matters on one hand, and the non-permanent members whom are not given this power on the other hand.

Therefore, the voting method of the Security Council is based on the basis of the distinction between procedural and substantive matters on one hand, and between permanent and non-permanent members on the other hand.

\footnotetext{
${ }^{2}$ Dr. Ali Saad At-Tahir, Al-QanunAljina'i Ad-Dawli, Aljazaat Ad-Dawalia (International Criminal Law, International Sanctions) Beirut, 2000, p. 213.

${ }^{3}$ This chapter gives the Security Council broad discretionary power to consider the cases submitted thereto. When the Council considers the cases submitted thereto and considers them threatening to peace, or violating it, it shall handle them and take the necessary measures. These measures are summarized as follows:

1. Temporary measures (inviting the contestants to take whatever measures the Council deems necessary or desirable).

2. Measures that do not warrant the use of violence (cessation of economic relations and all kinds of transportation, and partial or total severing of relations)

3. Violent measures (the use of violence such as the blockade and hostilities), as previous measures did not fulfill the purpose.

Dr. Muhammad Al-Magzoub, At-Tanzeem Ad-Dawali (International Organization): An-Nazariat Al-AmaWa Al-Munazamat Al-AlamiyyaWa Al-Iqlimia (General Theory and International and Regional Organizations) University House, 1994, pp. 188199.

${ }^{4}$ Dr. Mahmoud Marshaha, Al-Munazamat Ad-Dawlia (International Organizations) University of Aleppo Press 1996, pp. 138 and beyond.

Dr. Muhammad Saeed Al-Dakkak, Al Tanthim Al Douli (International Regulation), Al Dar Al Jamieia, 1992, page 317 onward.
} 
The Charter that differentiates between procedural and substantive matters did not set a clear and precise standard to distinguish them, but the joint statement issued by the Big Three in San Fransisco Conference has clearly stated that, the matters mentioned in Articles " 28 " to " 32 " of the Charter is considered procedural matters that require, in accordance with Article " 28 " of the Charter, at least nine votes out of the number of member countries, which are fifteen, without distinction between permanent and non-permanent members.

As for substantive matters, what is not considered of the procedural matters is considered substantive matters, as they require, in order to take a decision regarding them, the approval of at least nine of the members, provided that the votes of the permanent members are in agreement, which means granting the permanent members of the Security Council the Veto Power. Therefore, if, in any case, a permanent member objects to a specific draft resolution that the Council is voting on-- then the rest of the Council members shall refrain from voting, and the draft shall be refuted. According to what is customary in the Security Council, if a member (permanent or non- permanent) abstains or is absent from voting during the voting on a draft resolution that the council votes on, then its vote is not considered an objection, but rather means lack of participation in the vote in either way. Hence, absenteeism or abstention from voting does not affect the validity of the Council's decisions, because the basic principle is to only count the votes of those present and participating in the vote.

The majority of jurists also agreed to consider absenteeism or refrain from attending to abstain from voting, especially when it occurs deliberately with the intention of disrupting the work of the Council, a violation of the Charter (paragraph / 1 / of Article / 28 /). 5

We believe, according to what we have mentioned, that the issue of referring a situation by the Security Council to the International Criminal Court, which was stated in the statute of the court, is considered a substantive matter and not a procedural matter, considering that procedural issues were identified in the joint statement issued by the Big countries at the San Francisco Conference, as mentioned above, and the disagreement over determining the nature of a matter, whether it is a procedural or a substantive matter, is in itself a substantive matter.6

That means the Big Five Countries shall maintain the Veto Power in deciding the nature of the matter under dispute. Therefore, referring a situation to the court needs the approval of nine members, including those having the Veto Power, and if any of these members objects to referring a situation to the International Criminal Court, then the rest members shall also refrain from considering it any further.

According to what is mentioned above, it becomes clear, at least theoretically, how difficult it is for such a decision to be taken by the Security Council,7given the difficulty of getting unanimously nine votes, including those of the five permanent members of the Council. What is more complicated is that the United Nations Charter did not prevent a member of the Council (permanent or provisional) from voting on a dispute of which it is a party, with the exception of the decisions taken in implementation of the provisions of Chapter VI and paragraph "3" of Article "52" (A "27" P "3"). Therefore, if the referral decision is issued under Chapter VII, a member of the Security Council, even if it is a party of the dispute, can participate in voting on it. A country is considered a party of the dispute if the accused or the victims are its nationals, or that the crime has occurred on its territory. However, it is a bit relieving that it is customary (in some cases and if the interests are not at stake) that the member can refrain from voting according to its will if the the complaint is filed against it. 8

\section{Second: The extent to which the Security Council's decision is mandatory for the Prosecutor and Pre-Trial Chamber:}

If the referral is made to the Prosecutor by a country which is a party in which one or more of the crimes specified in the statute appears to have been committed, and if the Prosecutor finds that there is no reason to accuse a certain person or more, it is then permissible for him not to initiate an investigation based on the lack or insufficiency of evidence, or that the act does not constitute a crime, or that the crime committed does not fall within the jurisdiction of the court. However, if he finds justification to initiate an investigation, he must carry out the investigation.

\footnotetext{
${ }^{5}$ Dr. Muhammad Al-Magzoub, ibid. page 191.

${ }^{6}$ Despite that the joint statement issued by the Big Countries at the San Francisco Conference has mentioned that the it is considered a procedural matter to adjudicate if a matter is considered a procedural or a substantive matter, the Big Five Countries insist that it is a substantive matter so that they can use the Veto Power if needed, ibid, p. 189.

${ }^{7}$ However, if the interests of one of the permanent members, especially the most powerful among them, lean towards condemning a person who is a citizen of the country which is an enemy, as it damages the interests of this member, then the matter will not be difficult as this.

${ }^{8}$ Dr. Muhammad Al-Magzoub, ibid. p. 191.

84
} 
If the Prosecutor finds that he is entitled to initiate the investigation on his own initiative on the basis of information of crimes related to the jurisdiction of the court, then he may, for this purpose, receive information from any of the entities or sources that he consider reliable and appropriate, but permission must be obtained from the Pre-Trial Chamber to conduct the investigation, though the Pre-Trial Chamber's refusal to authorize the investigation does not prevent the Prosecutor from submitting a subsequent request based on facts, or new evidences related to the same case "A15".

As for the referral request submitted by the Security Council , the Statute, although it had granted a limited discretion to the Prosecutor, it did not adequately distinguish between the discretion of the Pre-Trial Chamber with respect to granting a permission to conduct the investigation or not. Therefore, a distinction must be made between the competences and powers of the Security Council in the area of preservation of international peace and security established under Chapter VI of the Charter (Pacific Settlement of Disputes), and those established under Chapter VII (Action with Respect to Threats to the Peace, Breaches of the Peace, and Acts of Aggression). In the first case, the Security Council can recommend that the conflict shall be resolved if all parties request it to do so (A " 38 ").

However, member countries, or non-members, as well as the Secretary-General and the United Nations General Assembly have the right to alert the Security Council to any conflict or situation that would endanger international peace and security (Articles "9-11-35-37".

In fact, the Security Council may intervene on its own accord to discuss any dispute or a situation that might lead to international conflict or give rise to a dispute. (A “34”).

In all of these cases, the Council may recommend any procedures or methods of peaceful settlement it sees suitable that the dispute parties can resort to, but without recommending a substantive solution to the dispute itself (A36). If the methods of a peaceful settlement to which the parties resorted spontaneously, or those recommended by the Security Council, fail then, in this case, the Council may recommend what it deems appropriate to resolve the dispute, i.e. it proposes the framework and conditions for the settlement (A37). However, in all of these cases all that the Security Council has the right to do is to give non-binding recommendations to the parties in dispute. 9

As for the second case (that is, Action with Respect to Threats to the Peace, Breaches of the Peace, and Acts of Aggression) the Security Council possesses broad and binding powers, because it intervenes in this case as a deterrent authority whose mission is to keep the peace or restore it, and here it is noted that the Security Council has enormous discretionary and real powers: The Security Council is that which determines if the act is considered an aggression, a threat or a breach to the peace. 10

Article 53 of the Statute clarified that if the referral decision was issued by the Security Council and it became clear to the Prosecutor, after preliminary investigations, that there was not a sufficient basis for prosecution, then he shall inform the Pre-Trial Chamber and the Security Council of the result that he had reached, and the reasons for it. The Pre-Trial Chamber may, on its own initiative, or at the request of the Security Council, review the decision of the Prosecutor General, and request him to reconsider that decision, which becomes effective only if it is approved by the Pre-Trial Chamber..

However, if the Prosecutor concludes from his preliminary investigations that there are reasons justifying for prosecution, then we believe, in this case since the Statute did not address this case and because the referral decision will be issued under Chapter VII of the Charter of the United Nations, that this decision will undoubtedly have the mandatory power. Therefore, the Pre-Trial Chamber does not have to impose permission to initiate an investigation, and the court must issue its ruling, whether it is a guilty or acquittal verdict.11

Thus, we go against jurisprudence in some aspects it used in this regard, as after initiating the following questions: What is referral by the Security Council? Does it mean that the Council has to submit a complaint to the court or is it intended that the Council draw the court's attention to a specific situation?

It is established that the referral to the court by the Security Council is intended to draw the court's attention to the occurrence of a crime within its jurisdiction. 12

\section{Section II: The Security Council's authority to defer investigation or prosecution before the court:}

\footnotetext{
${ }^{9}$ Dr. Mahmoud Marshaha, ibid, P 135.

${ }^{10}$ Dr. Hassan Nafaa, Al 'umam Al Mutahidat fi NsfQarn (The United Nations in Half a Century) Alam Al Maarifa Series/ Publications of the National Council for Culture and Arts, Kwait, 1995, P 103.

${ }^{11}$ Whereas the matter was not the same in the Rwanda Tribunal, Article 16 of its Statute stipulated the independence of the prosecution in this court despite being appointed by the Security Council, (Dr. Muhammad Sharif Bassiouni, Al-mahkma Algina'aya Al-dawlya, Dar Al-Nahda Al-Arabia, Cairo, 2001, P 57).

${ }^{12}$ Dr. Muhammad YusefAlwan, purplish of Al Qanun Al Duwali Al 'Iinsani, as part of the book: Dirasatfeh Al-qanoon Aldawly Al-a'nsaany, ICRC publications, 2000, P 214.
} 
The Statute of the International Criminal Court stipulates that the Security Council may, according to a decision issued by it in accordance with Chapter VII of the Charter of the United Nations, request the International Criminal Court to defer investigation or prosecution for a duration of twelve months, and the Council may limit this request to the same conditions (A16).

In order for the Security Council to perform its duties optimally, and indeed achieve security for the international community, it is possible to provide assistance thereto, whether by some organs of the United Nations itself or by countries, according to the following details:

- The right to submit issues to the Security Council:13

The right to submit issues to the Security Council is related to the issue of inviting the Council to a meeting, not to be convened because it is a permanent body14. The meeting shall, at the invitation of the President of the Council itself, study a specific topic submitted by the Secretary-General of the United Nations, or the General Assembly or one of the member or non-members, as follows:

1. Secretary-General of the United Nations: A he is entitled to file an issue to United Nations Security Council, if this issue threatens International Peace and Security pursuant to Article 99 of Charter, which stipulates that "The SecretaryGeneral may bring to the attention of the Security Council any matter which in his opinion may threaten the maintenance of international peace and security.," accordingly, if Secretary-General of the United Nation decides that the extension of investigation shall threatens International Peace and Security, he shall be entitled to refer it to United Nations Security Council.

2. United Nations General Assembly: In addition, It is entitled to file any issues to United Nations Security Council, if it is proper, according to Article 11 of Charter.15 Accordingly, United Nations General Assembly is entitled to refer it to United Nations Security Council if the extension of investigation shall threatens International Peace and Security 3. Member states of the United Nations: Whether they are Member states of the United Nations or not, Whether they are Rome Statute of the International Criminal Court Members or not, as they are entitled to file any issue to United Nations Security Council, according to Article 35 paragraph 1 of Charter that states "Any Member of the United Nations may bring any dispute, or any situation of the nature referred to in Article 34, to the attention of the Security Council or of the General Assembly." Article 34 states that The Security Council may investigate any dispute, or any situation which might lead to international friction or give rise to a dispute, in order to determine whether the continuance of the dispute or situation is likely to endanger the maintenance of international peace and security." It is not necessary whether the State which brought the issue to attention, is a party in this situation or dispute or not. Accordingly, if the extension of investigation or filing the issue to the court shall lead to international friction or give rise to a dispute, Member State of the United Nations shall be entitled to brought this issue to the attention of the United Nations Security Council.

1- Non-member States of the United Nations: They are entitled to file an issue to United Nations Security Council according to Article 35 paragraph 2 that states "A state which is not a Member of the United Nations may bring to the attention of the Security Council or of the General Assembly any dispute to which it is a party if it accepts in advance, for the purposes of the dispute, the obligations of pacific settlement provided in the present Charter.'Therefore, State shall be a party, it shall be a party in dispute if the perpetrator(s) or victims are its nationals or if the crime committed within its borders, are in the jurisdiction of the court, in the dispute to bring to the attention of the Security Council that the proceed of prosecution before International Criminal Court may endanger international peace and security.

It is not necessary, in this case, that the State signed or consent to Rome Statute of the International Criminal Court, as the Non-party States, in Rome Statute, may accept the court jurisdiction.16

In order that United Nations Security Council can apply its powers to defer the investigation, or the prosecution before the International Criminal Court,as it is concluded from the article 16 of Rome Statute, two indispensable major conditions shall be required as follows:

A. If the investigation or prosecution proceeded with endangering international peace and security, and this is a natural and reasonable outcome of United Nations Security Council main assignment of , which stated in Article 39 of United Nations Charter:

\footnotetext{
${ }^{13}$ Dr.Iibrahim Al Shalbi, At-Tanzeem Ad- Dawali, An-Nazariat Al-Ama, Part I, 1986, P 315 and onward.

${ }^{14}$ Dr. Mahmoud Marshaha, Al-Munazamat Ad-Dawlia, ibid, P 131

${ }^{15}$ As the Article 11 paragraph 3 states that "The General Assembly may call the attention of the Security Council to situations which are likely to endanger international peace and security."

${ }^{16}$ Dr. Ali Abdul-Qadir Al-Qahwaji, International Criminal Law, AlHalabi Legal Publications, 2001, p. 150. 
The Security Council shall determine the existence of any threat to the peace, breach of the peace, or act of aggression and shall make recommendations, or decide what measures shall be taken to maintain or restore international peace and security, consequently it is clear that the Security Council has a significant discretionary power as it determines if a specific issue is considered as an act of aggression or a threat to the peace). 17

B. Obtaining the approval of nine of the fifteen votes in the Security Council, as if veto is applied by any of the five Permanent members of the United Nations Security Council, this means that abatement of suspension resolution draft, precisely it is necessary to apply the aforementioned measures, in the case of reference of an issue to the International Criminal Court by United Nations Security Council.

In addition to the term in which the United Nations Security Council is allowed to suspense the investigation or file a prosecution before International Criminal Court, the Rome Statute of the Court determines by renewable twelve months with the aforementioned conditions (according to a resolution issued by United Nations Security Council for twelve months at a time). 18

Accordingly, with the expiry of the suspension term and the issuance of a resolution to renew this term, the International Criminal Court to review the claim by default, without issuance of a resolution by United Nations Security Council in this regard.

In respect of the times which United Nations Security Council may renew its resolution, hence we think, whereas the provision is unconditional, United Nations Security Council may renew the said resolution at infinite times, without restrictions to certain suspension times, whenever the aforementioned conditions are fulfilled, and when the International Criminal Court conducts an investigation with a group of perpetrators charged with a crime or more in its jurisdiction, as the United Nations Security Council resolution to suspend the investigation, or the prosecution shall be applied thereon as whole due to the unconditionality of the provision,unless the United Nations Security Council resolution states otherwise, then the resolution shall be unacceptable at least morally as discussed later.

On other hand, as the United Nations Security Council resolution to suspend the investigation or prosecution, shall be issued subject to the chapter VII of United Nations Charter, it shall be definitely mandatory for International Criminal Court, as in the case of the reference of an issue by United Nations Security Council to International Criminal Court, accordingly, the Court shall, Once this decision is issued, suspend the consideration of the claim until the expiry of the following year to the issuance of the resolution, and after the expiry of the said term, the Court shall reconsider the claim unless the resolution was renewed.

\section{Second topic:}

\section{Assessment of the relation of International Criminal Court and United Nations Security Council.}

The main pleas that Rome Statute of International Criminal Court, the relation of International Criminal Court and United Nations Security Council.19

By reviewing the Rome Statute of the Court (Article/ 16-13), United Nations Security Council is entitled,according to Chapter VII of Charter, to refer any Lawsuit in jurisdiction of the Court, in addition to It is not allowed to commence or proceed the investigation or prosecution otherwise upon to United Nations Security Council request with a resolution issued thereby according to Chapter VII of United Nations Charter, and this request may be renewed.

In the Rome conference, there were numerous approaches in the debate of the relation between United Nations Security Council and the International Criminal Court according to Article /13/, as the Arab States and other States find it proper to give United Nations Security Council an authority to refer a case to the Court subject to Chapter VII of the Charter, with regard to the crime of aggression, and cease-and-desist the court for a specified period if the council deemed that.

As for the United States of America, Russia and China, find it proper to give the Council a full authority of referral a case to the court according to Chapter VI and VII of the Charter,with regard to the crime of aggression, and cease-anddesist the court indefinitely.

The third approach rejects giving the United Nations Security Council any authority, as the India and Mexico Iran and some Arab countries adopted that approach, on other hands, other Arab countries find it proper to give United Nations Security Council a restricted authority.20

\footnotetext{
${ }^{17}$ Dr. Hasan Nafaa, ibid, P.103.

${ }^{18}$ Dr. Muhammad YusefAlwan, ibid, p. 217.

${ }^{19}$ Dr.Mokhtar Ali Saad At-Tahir, Al-QanunAljina'i Ad-Dawli, Aljazaat Ad-Dawalia (International Criminal Law, 2000., P 213.

${ }^{20}$ Dr. Al-Tahir Mukhtar Ali Saad, ibid, P. 213, Quoted from the report of the Libyan delegation on the diplomatic conference achievements on the establishment of an international criminal court in Rome, 6/15 to 7/17/1998, p. 26.
} 
The relation between International Criminal Court and United Nations Security Council even if some consider it as an application to the authority of United Nations Security Council, as stipulated in United Nations Charter, special Chapter VII which give United Nations Security Council a Supreme political authority, in respect of the issues which involve maintaining or restoring international peace and security, in addition, Article 39 of Chapter VII gives United Nations Security Council the authority to impose penalties to maintain or restore international peace and security.21 United Nations Security Council may abuse the granted authorities, accordingly, it shall negatively affect the international peace and security, we shall discuss the essential potential beneficiaries of such relation (Section I), then the main faults of such relation (Section II)

\section{Section I: The beneficiaries of the relation of the International Criminal Court and United Nations Security Council:}

The significance of the authority granted to United Nations Security Council, as International Organizations, in addition, it is considered as a proxy of the member of United Nations to fulfill the duties of maintaining or restoring international peace and security, according to Article 24 paragraph 1 "In order to ensure prompt and effective action by the United Nations, its Members confer on the Security Council primary responsibility for the maintenance of international peace and security, and agree that in carrying out its duties under this responsibility the Security Council acts on their behalf."

The significance of United Nations Security Council represents in assigned duties of maintaining or restoring international peace and security, it represent a significant break through in developing the international organization, as it was given to it according to the provision of Chapter VII of the Charter, the authority to take various measures, thus, the idea of collective security was fully realized for the first time in the history of international organization, as it includes its two parts: Preventive and curative security.22

Accordingly, Rome Statute of United Nations Security Council, the authority to issue a referral resolution to the International criminal court, United Nations Security Council, the Council considers a crime or more stipulated in Rome Statute, was committed, the validity to suspend an investigation or prosecution before the Court for a full renewable year.

The authority of United Nations Security Council to refer cases to the Court, has its grounds including maintaining international peace and security according to United Nations Charter, it is natural that United Nations Security Council is entitled to request court intervention, and execute Criminal procedures related to any of defined crimes.23

Undoubtedly, giving such authorities to Security Council, in addition to being a party to Rome Statute and Public prosecutor could reduce violation cases of Human Rights Law and International Humanitarian Law and reduce such committed crimes. In addition, In case of occurrence such crimes, giving such authorities to Security Council will prevent the perpetrator from escaping justice. This is what has been asserted on preamble of RomeStatute.24

In a way which leaves no room for doubt, this will bring security and assurance to the international society and UN resolution shall be deemed binding at this case under Chapter VII of the Charter of the United Nations. If Public prosecutor has considered reasonable grounds to continue investigation of the subject matter proposed by the council. At this case, Pre-trial chamber has no right for not granting investigation permit contrary to the case when the case suited by State party; or when Public prosecutor has decided to continue investigation. This means that the court will scrutinize untilreaching a final judgment of conviction, acquittal or irresponsibility and the Pre-Trial Chamber shall not have the minimum discretion to interfere.

If juridical system of the state holding the case is unable to carry out the appointed tasks; or the procedures taken by the court aim to prevent the concerned persons from bearing criminal responsibility towards crimes falling within the jurisdiction of the court; or judgment is not fair.

\footnotetext{
${ }^{21}$ Dr. Muhammad Sharif Bassiouni, ibid, p. 57.

${ }^{22}$ Dr. Ibrahim Shalaby, Ibid, P 307.

${ }^{23}$ Dr. Muhammad YusefAlwan, ibid, p. 213.

Dr. Riad Al-Daoudi, Tareikh Al-a'laqat Al-dawlya (History of International Relations), Dar Al-kitab Press, Damascus, 1992. Page 25

${ }^{24}$ The preamble states that: "States Parties affirms that the most serious crimes of concern to the international community as a whole must not go unpunished and that their effective prosecution must be ensured by taking measures at the national level and by enhancing international cooperation, determined to put an end to impunity for the perpetrators of these crimes and thus to contribute to the prevention of such crimes" See preamble of Rome Statue for International Criminal Court.
} 
In case there is unreasoned delay in the procedures with an intention to prevent the concerned person from being brought to justice, the Security Council has to bind the state25 to leave this case to the International Criminal Court to start investigating at and request the surrender of the concerned person according to what is mentioned at Statute (Articles no.79-90).

If any State rejects the surrender of concerned person, Council (assembly) of States parties has to suspend the membership of given state in the court and the rest of states parties may decide to suspend diplomatic or commercial relations with this State.26

It is noteworthy to mention that UN has to right to interfere on similar situations as this except in the case when it has referred of the matter to the court. 27

This what could be concluded from paragraph no.7 pf Article no.87 of Rome Statute that has decided: "Where a State Party fails to comply with a request to cooperate by the Court contrary to the provisions of this Statute, thereby preventing the Court from exercising its functions and powers under this Statute, the Court may make a finding to that effect and refer the matter to the Assembly of States Parties or, where the Security Council referred the matter to the Court, to the Security Council."

Furthermore, such authority granted to the Security Council enable it to avoid a case if the crime occurred on the territory of a State that is not State parties, or that the perpetrator is one of its nationals and rejects the jurisdiction of the court, since in this case the jurisdiction of the International Criminal Court does not take place unless the request was made by the Security Council exclusively. 28

It also limits the Security Council authority to refer cases to the International Criminal Court, if it does not deny its need to establish new special tribunals similar to the International Criminal Tribunal for the Former Yugoslavia and the International Criminal Tribunal for Rwanda,29 Accordingly, avoiding the mistakes that were directed to both Courts as they were subsidiary bodies related to the Security Council; or the negative consequences thereof, as they are related to the conditions of their establishment, and their jurisdictions shall have no effect after the completion of assigned duty.

The Security Council may, pursuant to resolution issued upon its authority and under Chapter VII of Charter to give the court the jurisdiction to investigate at the committed crimes before the application of the said Statute, 30 to move beyond what is called court future jurisdiction.

However, in order to achieve the desired purpose of this authority (referral) granted to Security Council, this should be done with Good Faith to achieve international peace and security especially the five permanent members of the Council, which has a constant right to suspend any authorities by using the right of (veto).

As for the authorities of Security Council to investigate or prosecute before the court, they are not justified. Therefore, there is no positives to be mentioned in respect of this. This is what will be shown down below.

Section II: The negative consequences resulted from the relation of International Criminal Court with Security Council:

\footnotetext{
${ }^{25} \mathrm{We}$ believe that if this considered as an interfere in the international relations of the concerned state, it will have a support at UN charter as Article no.2-7 state the following: "Nothing contained in the present Charter shall authorize the United Nations to intervene in matters which are essentially within the domestic jurisdiction of any state or shall require the Members to submit such matters to settlement under the present Charter; but this principle shall not prejudice the application of enforcement measures under Chapter Vll." Beside that it is also supported by United Nations General Assembly approval at 1977. This this resolution implies to provide humanitarian assistance for victims of natural disasters and similar urgent situations. Mahmoud Mashrahah, Al-Wajeez in Public International Law, 1994, P,138. This in case the essence of the provision has been adopted instead its literal abstract meaning.

${ }^{26}$ As we believe, this does not contradict with the International law regulations even if the States parties have diplomatic or commercial connections or ties to this State which by taking the action of not to surrender the concerned person has breached its obligations under Rome State. This gives the States parties the right to suspend their relation with this state as per Rome Statue.

${ }^{27}$ Dr. Muhammad Sharif Bassiouni, Taqeem Al-nizam Al-asasy L-al mahkma Al-gina'ya Al-dawlya (The Assessment of Statue of International Criminal Court) as part of book: Dirasatfeh Al-qanoon Al-dawly Al-a'nsaany (studies on Humanitarian International Law), ibid, P.458.

${ }^{28}$ See similar opinions of Muhammad YusefAlwan, ibid, p. 216; and also Bassiouni, Al-mahkma Al-gina'aya Al-dawlya (International criminal Court, P.165).

${ }^{29}$ Dr. Muhammad YusefAlwan, ibid, p. 213.

${ }^{30}$ Dr. Ali Abdul-Qadir Al-Qahwaji, ibid, P.330.
} 
It has been shown that- by reviewing the situation involved by Security Council with International Criminal Courtmajority of States participating at the Conference oppose the existence of this relation. As this relation shall affect the due neutrality of the Court as the Security Council take decisions based on political considerations, It is a political council not a legal or statutory body. 31

These political considerations have it role in affecting Security Council resolutions- this is what happens, as currently, these authorities given to security council, according to Rome Statute, can be considered nothing but the first and main factor hindering the procedures of International Criminal Court to adhere to Humanitarian International Laws and Human Rights Law.

Therefore, we shall discuss, at first, the most negative consequences that could result by referring a case to the court by Security Council; then we shall discuss the negative consequences resulted by suspending investigations or prosecution before International criminal court by Security Council.

\section{The Referral Negatives:}

Despite the positives of giving the Security Council, the right to refer cases to the court as end to perpetrator who threat the international security; and as a way to reduce cases of escaping justice beside any other previously mentioned positives. By granting this authorities to Security Council, it means that it breaches the basic principles of Rome Statute as a principle of complementarity; Non-bis in idem. In addition, it is a breach to the Principles of Public International Law as the relative effect of treaties and non-intervention principles in the internal affairs of States.

If we assume that one of the states, whether it is a party to the Rome Statute, or not and lies upon it the responsibility to consider the crimes stipulated in the said Statute, whether it is personal or regional jurisdiction, and at the same time able to carry out its judicial duties, and is willing to do so.

Does the Security Council has the right to issue a resolution to refer indictee to the International Criminal court?

It appears that Security Council shall not have that right as the Rome Statute states that the court shall accept admit the case or not.

The case is being investigated or prosecuted by a State, which has jurisdiction over it, unless the State is unwilling or unable genuinely to carry out the investigation or prosecution;

The case has been investigated by a State which has jurisdiction over it and the State has decided not to prosecute the person concerned, unless the decision resulted from the unwillingness or inability of the State genuinely to prosecute; (Article no.17).

The Rome Statute is an international convention; thus, it shall be inconformity with UN charter. Even in case of incompatibility, the provision of Charter shall be subsisting on the provisions of the convention whether it has been formerly stated or not.32

The Rome Statute does not address the issue of possibility of issuance referral resolution by Security Council. If the case is represented before the court of competent state, we believe that the Security Council has given it the authority to issue this resolution; therefore, it could exclude those from holding these authorities of International criminal Court. Accordingly, principle of complementarity that has been referred at Rome Statute preamble: "Emphasizing that the International Criminal Court established under this Statute shall be complementary to national criminal jurisdictions".

The first Article of the said Statute again asserts on this principle.

Principle of Complementarity between International Criminal Court and the National Criminal Jurisdiction is one of the most basic principles upon which the said court is established.

This principle has been widely approved starting from preparatory work for establishing the court. The Court is meant to complement the national jurisdiction not to take precedence over it. This is the case with Ad hoc International court that give priority to national jurisdiction. The Court has been established not to replace the national jurisdiction, but to interfere at the most serious cases when "the internal criminal justice systems do not exist or are ineffective", as mentioned at ILC draft".33

By giving this authority by Security Council, the person in question shall be prosecuted before both State national court and International Criminal Court. This is not compatible with Non bis in idem.

\footnotetext{
${ }^{31}$ Dr. Mahmoud Mashrahah, Al-Wajeez in Public International Law, 1994, P.52.

${ }^{32}$ Article no. 103 of Charter states that: "In the event of a conflict between the obligations of the Members of the United Nations under the present Charter and their obligations under any other international agreement, their obligations under the present Charter shall prevail".

${ }^{33}$ Dr. Muhammad YusefAlwan, ibid, P.218. 
Hereby, the person, who has been prosecuted before any court for any action shall constitute a crime as per Statute, shall be prosecuted again before for the same action before the International Criminal Court except that the proceeding by the court has been taken to protect the concerned person from holding any criminal responsibility towards crimes under court jurisdiction; or that the court has not been independent and impartial in accordance with the recognized due process under international law, or has been conducted in a manner inconsistent with the intention to bring the person concerned to justice.(Article 20/paragraph no.3)

We assume that the prosecution is brought impartially, fairly, independently with an intention to bring the perpetrator to justice.

If the UN resolution implies referral of case, before the State court that is not a member of Statute, to the International Criminal Court especially in case that this State is able or desiring to fulfill its obligations to the fullest, it means that this resolution undoubtedly contradict with relative effect of treaties principle. The general principle is that the relative effect of treaties do not apply on non-member States; thus, they may have no rights or obligations in accordance with the ancient rules of jurisprudence: (Pactasuntservanda). Vienna Convention on the Law of Treaties states in Article no.34: "A treaty does not create either obligations or rights for a third State without its consent."34

We believe that this resolution is considered as an interference at internal affairs of the given country, this is banned as per the Article 2/7 of the UN charter whether this State is a member of the Rome statute or not- in case that judicial system is just and the investigation procedures are carried out with an intention to bring the person in question to justice. In case it is not, this resolution is supported by the UN Charter and General Assembly.

\section{Deferral Negatives:}

Article no. (16) of Rome Statute, in respect of Singapore initiative35, gives the Security Council a serious authority imply paralyzing the court activities and deferring the investigations and prosecution. This article states that investigations may not be proceeded as per the Statute for 12 months based on the Security Council resolution to the court under the chapter VII of UN charter. The Council may renew this request with the conditions. The provisions of Charter gives an authority to the security council by which it can suspend the activities of the International Criminal Court or it can also diminish the role; it has the authority to stop the prosecution procedures, and to stop continuation at given case for a year, and it is renewable to unlimited number of years, at events of disturbance and threat of international security and peace. The seriousness of such situation can be imagined by the assumption that the Security Council provide aid to the member state at Statute and by acceptance of the jurisdiction of the Court to prevent the International Criminal Court from adjudicating crimes taken place at territory of that State or by its nationals36. Thus, politics interfere with jurisdiction despite that both should be separated.37

Likewise, it is agreed that the purpose of any legal system is in addition to punishing the perpetrator of the crime for the actions that endanger the security of the community and its entity, preventing the recurrence of such crimes in the future from those who are asked to commit themselves, and this is called the policy of deterrence.

This, certainly, will not happen if the trial procedures are not proceeding, and therefore the ruling is swift and decisive without prejudice to the accused's right to defend himself, and thus assures the international community that his rights are preserved and his dignity is protected.

However, how can all this be achieved, if the Security Council has the right to prevent the court from starting or continuing the investigation for a full year, while this period may be renewed indefinitely?

In the event that the International Criminal Court begins investigating a group of persons accused of one of the crimes of the court's jurisdiction, and on the assumption that the Security Council issues a resolution to defer the investigation, or prosecute one of them, or some of them, but not others. Such a decision may produce results that do not serve the security and safety of the international community, because it may provoke the ire of some countries, and thus lead to disruption of the path of international peace and security.

\footnotetext{
${ }^{34}$ Dr. Muhammed Aziz Shokry, Madkhal Ella Al-qanon Al-dawli Al-a'm (Introduction to Public International Law), ibid, P.447.

${ }^{35}$ Dr. Muhammad YusefAlwan, ibid, p. 217.

${ }^{36}$ USA and Israel have refrained to sign the Statue of International Criminal Court until the end of the year 2000 where USA finally decide to sign; then after two hours, Israel has signed because USA presidents undertakes before the Israeli Prime Minister Ariel Sharon not to allow the referral of any Israeli in charge to the International Criminal Court. Dr. Dhafer Bin Khadra, Mahakim Al Jaza' Al DuwaliawaJarayimHukkam 'Israel, 2001, P.42. Athough USA has recently withdrawn its signature.

${ }^{37}$ Dr. Ali Abdul-Qadir Al-Qahwaji, ibid, P.344.
} 
It is also not borne in mind that such a suspension does not contradict with what was stipulated in Article / 67 / of the statute of the court, as it decided that the accused has the right "to be tried without any undue delay."

It is difficult for an innocent person to remain indicted for a long time in a crime in which he has no relation to it. As a result of what was mentioned, it could be said that this authority granted to the Security Council to defer the investigation or prosecution includes, without a doubt, the possibility of denying justice, and we find no justification for it. As there no dangerous situation that threatens international peace and security - as some claim - this dangerous situation will not affect the work of the court, if the United Nations represented by the Security Council adopts a policy of collective security, and restrain the state that tries to undermine international peace and security.

\section{Conclusion:}

The issue that makes one wonder and raise many questions is the relation between the International Criminal Court and the Security Council, as this issue can greatly impede the work of the court. In order for the court to go on its right track, it must prosecute and punish the perpetrators of the crimes stipulated in its statute with a single standard.

We may find those who commit crimes against international security under the sight and hearing of the world, or with the support of a country, and this is doubtful if the Security Council interferes in the work of the court, especially after giving the council the power to defer an investigation or prosecution before the court for a full year with the possibility of renewing more than once, because the Security Council is a political body and political passions and considerations play a large role in its resolutions, especially at the present time, and this does not, of course, fit with what is hoped from the International Criminal Court.

However, the hope for the abolition of those powers granted to the Security Council vis-à-vis the court, and other shortcomings that was mentioned, shall remain present, as the statute of the court may be modified.

\section{References}

Dr. Ibrahim Al Shalbi, At-Tanzeem Ad- Dawali, An-Nazariat Al-Ama, Part I, 1986,

Dr. Hassan Nafaa, Al 'umam Al Mutahidat fi NsfQarn (The United Nations in Half a Century) Alam Al Maarifa Series/ Publications of the National Council for Culture and Arts, Kwait, 1995

Dr. Riad Al-Daoudi, Tareikh Al-a'laqat Al-dawlya (History of International Relations), Dar Al-kitab Press, Damascus, 1992

Dr. Dhafer Bin Khadra, Mahakim Al Jaza' Al DuwaliawaJarayimHukkam 'Israel, 2001

Dr. Ali Saad At-Tahir, Al-QanunAljina'i Ad-Dawli, Aljazaat Ad-Dawalia (International Criminal Law, International Sanctions) Beirut, 2000

Dr. Ali Abdul Qadir Al-Qahwaji, Al-Qanoon Al-Janaie Ad-Dawli, ManshuratAlhalabiAlhuquqia, 2001

Dr. Muhammad Al-Magzoub, At-Tanzeem Ad- Dawali (International Organization): An-Nazariat Al-AmaWa AlMunazamat Al-AlamiyyaWa Al-Iqlimia (General Theory and International and Regional Organizations) University House, 1994.

Dr. Muhammad Saeed Al-Dakkak, Al Tanthim Al Douli (International Regulation), Al Dar Al Jamieia, 1992

Dr. Muhammad Sharif Bassiouni, Al-mahkma Al-gina'aya Al-dawlya, Dar Al-Nahda Al-Arabia, Cairo, 2001.

Dr. Muhammad YusefAlwan, purplish of Al Qanun Al Duwali Al 'Iinsani, as part of the book: Dirasatfeh Al-qanoon Al-dawly Al-a'nsaany, ICRC publications, 2000

Dr. Mahmoud Marshaha, Al-Munazamat Ad-Dawlia (International Organizations) University of Aleppo Press 1996

Dr. Mahmoud Mashrahah, Al-Wajeez in Year International Law, 1994

Dr. Mokhtar Ali Saad At-Tahir, Al-QanunAljina'i Ad-Dawli, Aljazaat Ad-Dawalia (International Criminal Law, International Sanctions, 2000 